\title{
Heavy metal contamination in some soils of the McMurdo Sound region, Antarctica
}

\author{
G.G.C. CLARIDGE', I.B. CAMPBELL', H.K.J. POWELL'², Z.H. AMIN² and M.R. BALKS ${ }^{3}$ \\ ${ }^{1}$ Land and Soil Consultancy Services, 23 Viewmount, Nelson, New Zealand \\ ${ }^{2}$ Department of Chemistry, University of Canterbury, Christchurch, New Zealand \\ ${ }^{3}$ Department of Earth Sciences, University of Waikato, Hamilton, New Zealand
}

\begin{abstract}
Soil samples from eight sites at Marble Point and Pram Point, McMurdo Sound region, contaminated by human activities were examined for heavy metal content, using sequential extraction methods. The redistribution of lead, zinc and copper arising from point sources of these metals was demonstrated. The levels found are not considered to represent serious pollution but do indicate that human activities can change the chemistry of the Antarctic environment in localized areas.
\end{abstract}

Received 11 April 1994, accepted 26 September 1994

Key words: copper, zinc, lead, soil, pollution

\section{Introduction}

Antarctic ecosystems are probably the simplest of any in the world because of the exceedingly cold climate, the absence of precipitation and significant vegetation, and the very slow rate at which soil weathering takes place. After almost four decades of intensive scientific activity in the McMurdo Sound region of Antarctica, there is now an increasing awareness of the potential impact of humanactivities on the Antarcticecosystems. However, while the soils have been widely studied, there are few quantitative data available to provide measures of either the rate at which natural processes occur, or the extent to which disturbance of the ecosystem by human activities may have taken place.

In 1990, while carrying out studies of soil moisture in the active zone and permafrost at Marble Point, debris from a construction camp in use in 1958/59 was observed scattered about the soil surface at the old camp site. This included metallic sut stances as well as organic debris of various kinds. At some sites, where material had been piled up and burnt, ashes, nails, metal scraps and other debris were present.

Because some of the metal items at the soil surface, particularly copper, were strongly oxidized, the soils at several sites were sampled to determine the extent to which metal contamination may have leached into the soil. For comparative purposes, a soil from a site close to the construction campsite that showed no obvious signs of disturbance was also sampled. In addition samples were also collected at Scott Base, on Ross Island, from a site where an old building had recently been removed. The results of the analyses of these samples are reported here.

\section{Materials and methods}

\section{Description of soils and the soil environment}

The soils at Marble Point and Scott Base are typical of Antarctic soils found on tills on relatively young ( $<15000$ years) glacial retreat surfaces (Campbell \& Claridge 1987). They consist of bouldery sands with the $<2 \mathrm{~mm}$ fraction (excluding boulders and cobbles) around $50 \%$ and with silt and clay fractions commonly $<4 \%$ of the $2 \mathrm{~mm}$ fraction. The soils are unweathered, loose, and, because of the absence of plant cover, contain negligible amounts of organic matter. They are underlain by hard, ice-cemented permafrost at depths of between 35 and $60 \mathrm{~cm}$. At Marble Point, the soils are alkaline, with pHs between 8.0 and 9.5. They commonly contain $1-2 \%$ by weight of water-soluble salts, largely sodium chloride and sulphate, although smaller proportions of other ions are also present. At Pram Point, the salt contents are generally somewhat lower. Undisturbed soils have moisture contents ranging from $0.5 \%$ at the surface to $6-10 \%$ at the permafrost table. Within the permafrost, the frozen soil material is generally completely saturated with ice or even contain excess ice, although close to the surface of the permafrost there may be some pore space not completely filled with ice (Campbell et al. 1994).

The soils from Marble Point and Scott Base are formed in an environment which is moist, relative to most of Antarctica. Mean annual temperatures are about $-18^{\circ} \mathrm{C}$, although summer temperatures may rise to $+10^{\circ} \mathrm{C}$ or more (Sansom 1984), and the soils are occasionally moistened near the surface by summer snowfalls.

\section{Soil sampling}

The artefacts at Marble Point are believed to date from 1958/59 when a construction camp was established as a base for engineering investigations to assess the suitability of the area for a land-based runway. Following the abandonment of the project in 1959, some clean-up of the site took place and the buildings were subsequently demolished and removed. Remainingmaterial was crushed and partially buried by bulldozing during or subsequent to the tidy-up. The artefacts studied had been in 
position since that time.

At Marble Point, soil samples were collected in 1990 from directly beneath, at the edge of and $30 \mathrm{~cm}$ away from a crushed lead battery; from directly beneath a coil of wire, from beneath an accumulation of rusting cans, and from an adjacent site where no cans were present; from directly beneath the site of a rubbish fire; and from an apparently undisturbed site some $50 \mathrm{~m}$ from the battery site in an area where no artefacts were obviously present. The "undisturbed" site would doubtless have been walked over many times during the period of occupation of the camp. Details of the sample sites, including site numbers and sampling depths are given in Table I.

At Scott Base a site was sampled by the door of the former mess hut, which had been removed the previous season. Although no artefacts were seen, apart from a scatter of fine debris, kitchen rubbish was stored close by during the 25 years the building was in use and the site would have been subjected to continuous contamination from human activities during this time.

Table I. Sample depths and results of preliminary acetic acid extraction of samples. Element concentrations as $\mu \mathrm{g} \mathrm{g}^{-1}$ soil. nd $=$ not detected.

\begin{tabular}{lcccc}
\hline sample & $\begin{array}{c}\text { depth } \\
(\mathrm{cm})\end{array}$ & $\mathrm{Pb}$ & $\mathrm{Zn}$ & $\mathrm{Cu}$ \\
\hline
\end{tabular}

\begin{tabular}{|c|c|c|c|c|}
\hline \multicolumn{5}{|c|}{ Marble Point, beneath crushed lead battery } \\
\hline $578 b$ & $20-30$ & 28.5 & 0.36 & 0.04 \\
\hline $578 c$ & $30-40$ & 0.25 & 0.04 & $<0.04$ \\
\hline $578 \mathrm{~d}$ & $40-55$ & $<0.09$ & 0.03 & $<0.04$ \\
\hline $578 \mathrm{e}$ & $>55$ & 1.8 & 0.008 & $<0.04$ \\
\hline \multicolumn{5}{|c|}{ Marble Point, edge of battery } \\
\hline $643 a$ & $0-5$ & 11.6 & 0.61 & 0.05 \\
\hline $643 b$ & $10-15$ & 0.09 & 0.07 & $<0.03$ \\
\hline $643 c$ & $20-30$ & 0.33 & 0.03 & $<0.03$ \\
\hline \multicolumn{5}{|c|}{ Marble Point, $30 \mathrm{~cm}$ from battery } \\
\hline $643 \mathrm{~d}$ & $0-5$ & 3.7 & 0.24 & $<0.04$ \\
\hline $643 e$ & $10-15$ & 1.02 & 0.17 & $<0.04$ \\
\hline $643 \mathrm{f}$ & $20-30$ & 0.75 & 0.05 & 0.19 \\
\hline \multicolumn{5}{|c|}{ Marble Point, beneath copper wire on surface } \\
\hline $579 a$ & $0-2$ & nd & 3.3 & 10.6 \\
\hline $79 \mathrm{~b}$ & $2-5$ & nd & 1.6 & 0.18 \\
\hline \multicolumn{5}{|c|}{ Marble Point, rubbish dump sites under rusty cans } \\
\hline $580 \mathrm{a}$ & $0-2$ & $<0.09$ & 4.0 & 0.11 \\
\hline \multicolumn{5}{|c|}{ adjacent to 580 a but no cans present } \\
\hline $580 \mathrm{~b}$ & $0-5$ & $<0.09$ & 4.9 & 0.04 \\
\hline \multicolumn{5}{|c|}{ Marble Point, site of fire } \\
\hline $582 b$ & $0-3$ & 0.46 & 488 & 3.6 \\
\hline $582 \mathrm{c}$ & $3-10$ & $<0.04$ & 0.03 & $<0.04$ \\
\hline $582 \mathrm{~d}$ & $10-16$ & $<0.09$ & 1.30 & $<0.04$ \\
\hline \multicolumn{5}{|c|}{ Scott Base, old mess hut site, by door } \\
\hline $601 \mathrm{a}$ & $0-1$ & $<0.09$ & 8 & 0.24 \\
\hline $601 b$ & $1-8$ & 0.2 & 62 & 1.7 \\
\hline $601 c$ & $8-19$ & 0.64 & 10.6 & 1.3 \\
\hline $601 d$ & $19-29$ & $<0.09$ & 0.42 & 0.10 \\
\hline
\end{tabular}

\section{Sample collection and preparation}

Pits were excavated to the level of the ice-cement; samples were collected from the side of each pit using a clean trowel and stored in plastic bags. Samples were collected from the bottom of the pit upwards to avoid possible contamination from surface material falling down the sides of the pit. When returned to the laboratory, they were air-dried at $30^{\circ} \mathrm{C}$ and sieved through a $1 \mathrm{~mm}$ nylon mesh in a clean area. All subsequent analyses were on the $<1 \mathrm{~mm}$ fraction and were carried out in a class 100 clean room. Microscopic examination $(\times 50)$ did not reveal any particulate material $\left(\mathrm{PbO}_{2}, \mathrm{CuCO}_{3}, \mathrm{ZnO}\right)$ which could be ascribed to the point sources. However, the possibility that particulate matter contributed to the analyses remains.

\section{Metal extraction}

Sodium acetate was Aristar quality. Ammonia solution and acetic acid were purified by isopiestic distillation of the Analar $(\mathrm{BDH})$ reagents. Sodium pyrophosphate (Analar) was purified by electrolysis using a mercury pool cathode. Mercury used for electrolysis was BDH Aristar grade.

To obtain a preliminary estimate of the presence of heavy metals $1 \mathrm{~g}$ portions of each sample were extracted with $4 \mathrm{ml}$ $0.1 \mathrm{M}$ acetic acid and centrifuged at $3000 \mathrm{rpm}$ in a centrifuge of $100 \mathrm{~mm}$ radius.

The sequential extractions were designed to identify the forms in which the heavy metals are found in the soils by using extracting reagents which preferentially attack different sites. The methods used are applicable to soils with contents of clay minerals or organic matter typical of soils in temperate regions, which can absorb or complex metal ions. Antarctic soils have low clay contents, generally around $1-5 \%$, and extremely low organic matter contents. A four step extraction system was used. $1 \mathrm{~g}$ portions were extracted for one hour with $8 \mathrm{ml}$ of $1.0 \mathrm{M}$ ammonium acetate adjusted to $\mathrm{pH} 7$, centrifuged, and the supernatant removed. This procedure extracts water-soluble ions and those on the exchange complex of clays and organic matter (Chapman 1965). The residue was then extracted with $8 \mathrm{ml}$ of sodium acetate at $\mathrm{pH} 5$ for $2 \mathrm{~h}$, with intermittent agitation, centrifuged and the supernatant removed for analysis. This procedure removes metal ions bound to carbonates as well as other acid-soluble cations (Tessier et al. 1979). The residue from this step was then extracted with $8 \mathrm{ml}$ of $0.04 \mathrm{M}$ hydroxylamine hydrochloride in $0.5 \mathrm{M}$ acetic acid for $6 \mathrm{~h}$ at $90^{\circ} \mathrm{C}$ to extract metal cations bound to iron and manganese oxides (Tessier et al. 1979). The final extraction was made with $10 \mathrm{ml}$ of sodium pyrophosphate for $12 \mathrm{~h}$ to render organic matter and the associated metals soluble (Elsokkary \& Låg 1978).Residues were not resuspended and washed between sequential extractions, but the maximum carryover of extractant in consecutive steps was measured as $5 \%$. 
Analysis

In all extracts, the heavy metals $\mathrm{Pb}, \mathrm{Zn}, \mathrm{Cu}$ and $\mathrm{Cd}$ were determined using differential pulse anodicstripping voltammetry (DPASV) and, for Cu and $\mathrm{Zn}$, electrothermal atomic absorption spectrometry (ETAAS).

For DPASV, a PAR 384B Polarographic Analyser and PAR 303A hanging mercury drop electrode was used. Instrumental parameters were: drop size, medium; $\mathrm{N}_{2}$ purge, $10 \mathrm{~min}$; stir, fast; deposition time, 5-10 min; pulse height, $25 \mathrm{mV}$; scan rate $5 \mathrm{mv} \mathrm{s}^{-1}$. Typical measurements involved addition of $50 \mu \mathrm{l}$ (upper horizon)- $3000 \mu \mathrm{l}$ (lower horizon) of extract into $10 \mathrm{ml}$ Milli-Q water and $500 \mu \mathrm{l} 1 \mathrm{M} \mathrm{KNO}_{3}$ (Aristar) in the cell. Calibration was by spiking with standard solutions of analyte metals. All measurements were relative to a blank (instrument subtracted) prepared using the same aliquot of pure extractant and $\mathrm{KNO}_{3}$. Typical blanks were: for hydroxylamine, $0.4 \mathrm{ppb}$ $\mathrm{Cu}, 0.03 \mathrm{ppb} \mathrm{Pb}, 3 \mathrm{ppb} \mathrm{Zn}$; for $\mathrm{Na}_{4} \mathrm{P}_{2} \mathrm{O}_{7}, 0.05 \mathrm{ppb} \mathrm{Cu}, 0.03 \mathrm{ppb}$ $\mathrm{Pb}$; for acetate buffer, $2 \mathrm{ppb} \mathrm{Cu}, 4 \mathrm{ppb} \mathrm{Pb}, 0.8 \mathrm{ppb} \mathrm{Zn}$. Extracted humic matter was problematic only for pyrophosphate extracts, and particularly for $\mathrm{Cu}$ and $\mathrm{Zn}$ whose stripping peaks were most affected by humate tensammetric waves. $\mathrm{Cu}$ and $\mathrm{Zn}$ in these extracts were determined by ETAAS.

A GBC 2000 series furnace and controller and a GBC 903 spectrometer with PAL 1000 autosamplerwas used for ETAAS. Resonance lines used were $324.7 \mathrm{~nm}(\mathrm{Cu})$ and $213.9 \mathrm{~nm}(\mathrm{Zn})$; continuum source background correction was used routinely. Standards (0.01-0.06 ppm Cu, 0.004-0.035 ppm Zn) were prepared in the appropriate extract. Sample injections were $\mathrm{Cu}$ : $12 \mu \mathrm{l}$ of extract (diluted 2-100 fold with extractant) $+12 \mu \mathrm{l} 1 \%$ $\mathrm{HNO}_{3}$ modifier; $\mathrm{Zn}: 5 \mu \mathrm{l}$ (diluted 40-2000 fold) $+5 \mu \mathrm{l} 1 \% \mathrm{HNO}_{3}$ (for $\mathrm{NH}_{2} \mathrm{OH}$ extracts). Furnace conditions were: dry $110^{\circ} \mathrm{C}$ (ramp 30s, hold 5s), $140^{\circ} \mathrm{C}(20,5)$; ash $650^{\circ} \mathrm{C}(15,5)$; atomize $2400^{\circ} \mathrm{C}(1.0,2.0)$; clean $2500^{\circ} \mathrm{C}(1.0,1.0)$.

The results obtained by the two methods were in satisfactory agreement. For $\mathrm{Cu}$ the values were typically within $\pm 10-20 \%$ by the two techniques; for $\mathrm{Zn}$ the ETAAS values were typically $20-40 \%$ (average $25 \%$ ) higher, perhaps indicating incomplete separation of colloidal material during centrifugation. By ETAAS the lower limit of measurement $(5 \times \mathrm{DL})$ was c. $0.001 \mu \mathrm{g} \mathrm{g}^{-1}$ for $\mathrm{Cu}$ and $\mathrm{Zn}$. By ASV the lower limit was set empirically by the concentration of analyte, diluted 20 -fold, which gave a stripping current of $5 \mathrm{nA}$ after $10 \mathrm{~min}$ deposition. For $\mathrm{Cu}, \mathrm{Pb}$ and $\mathrm{Zn}$ this was $0.04,0.09$ and $0.03 \mu \mathrm{g} \mathrm{g}^{-1}$ respectively. For the wide range of analyte concentrations all DPASV RSDs were in the range $0.4-5 \%$ Humified organic matter was measured by the absorption of the pyrophosphate extract at $465 \mathrm{~nm}$, using fulvic acid solutions as standards. For more complete analytical details see Amin (1993).

\section{Results}

\section{Preliminary extractions}

Levels of zinc, lead and copper (Table I) were barely detectable in the extracts from the reference sites, but could be found in the samples from contaminated sites. Cadmium levels were below the detection limits at all sites (also for sequential extractions). A relatively large amount of lead, and smaller amounts of zinc, were detected under the battery and at the edge of the battery, while smaller but significant amounts were found $30 \mathrm{~cm}$ laterally. The concentration falls off in the horizon beneath the surface but increases again slightly at the permafrost level. Copper levels are low in the extracts but seem to follow the same trend.

This indicates that lead, zinc and possibly copper are released from the lead battery, and are present in particulate or absorbed form immediately beneath. Lead and zinchave moved laterally, presumably by wind or water, at least $30 \mathrm{~cm}$. Lead and zinc have also moved vertically downwards.

\section{Sequential extractions}

Organic matter estimated by measuring the absorption at $460 \mathrm{~nm}$ of pyrophosphate extracts of these soils, gave extremely low values of between 0.003 and $0.016 \%$. The highest value found was $0.016 \%$, in sample $580 \mathrm{a}$, collected amongst rusting cans, where some residual traces of organic matter might be expected. Similarly the soil at Scott Base (601a), subject to long-term contamination with organic matter (kitchen refuse, slops, etc.), also contained $0.015 \%$ carbon. Although these values are five times that of the reference site, they may be considered negligible. In general extractable metals were found predominantly associated with the oxide and carbonate phases. With the exception of site 579 , exchangeable metal represented a minor fraction $(<10 \%)$ of total extractable metal. This is consistent with the low organic content and low CEC of these poorly weathered soils. The maximum copper binding capacity for soil humic acids (HA) has been reported as $1.2 \times 10^{-3} \mathrm{~mol}$ (gHA) ${ }^{-1}$ (Powell \& Town 1993). Assuming 50\% Cin soil humic acid this binding capacity is equivalent to $24 \mu \mathrm{g} \mathrm{g}^{-1}$ in a soil with $0.016 \% \mathrm{C}$.

The sequential extractions which used somewhat more powerful extractants, yielded higher amounts of lead and zinc, particularly in the oxide form and (for $\mathrm{Cu}$ ) the organic forms at the reference site (Table II). There may be some slight contamination, derived from the burning of vehicle or heating fuels.

The sequential extractions of the lead battery site (Table III) showed that the bulk of the lead is associated with the oxide form or carbonates. Lead was originally present in the battery either as metallic lead or lead oxides in the plates, or as lead sulphate or lead ions associated with the electrolyte. The lead in the surface sample immediately below the battery could have fallen from the plate remnants as oxide. This has moved a little way down the profile and laterally, probably still in the particulate form. Lead in the ionic form has reacted with carbonate ions to precipitate as lead carbonate or perhaps the more stable hydroxy carbonate (white lead). This could account for the high concentrations of lead in both the oxide and the carbonate form at the permafrost surface. Some lead appears in the "organic" 
Table II. Results of acetic acid and sequential extractions of the reference site samples. Reference site situated $50 \mathrm{~m} \mathrm{~N}$ of site 578 . Values in $\mu \mathrm{g} \mathrm{g}^{-1}$.

\begin{tabular}{cccccccc}
\hline & & depth & acetic & \multicolumn{4}{c}{ sequential extractions } \\
& sample & cm & acid & exchg. & carbonate & oxide & organic \\
\hline $\mathrm{Pb}$ & $645 \mathrm{~b}$ & $0-5$ & $<0.01$ & $<0.09$ & $<0.09$ & 0.14 & $<0.09$ \\
& $645 \mathrm{c}$ & $5-20$ & $<0.01$ & $<0.09$ & $<0.09$ & 0.14 & 0.12 \\
& $645 \mathrm{~d}$ & $20-30$ & $<0.01$ & $<0.09$ & $<0.09$ & 0.14 & $<0.09$ \\
& & & & & & & \\
$\mathrm{Zn}$ & $645 \mathrm{~b}$ & $0-5$ & 0.11 & $<0.03$ & 0.4 & 1.4 & $<0.28$ \\
& $645 \mathrm{c}$ & $5-20$ & 0.15 & $<0.03$ & 0.7 & 1.0 & $<0.28$ \\
& $645 \mathrm{~d}$ & $20-30$ & 0.02 & 0.04 & 0.09 & 1.4 & $<0.28$ \\
& & & & & & & \\
$\mathrm{Cu}$ & $645 \mathrm{~b}$ & $0-5$ & 0.02 & $<0.04$ & 0.08 & 0.1 & 0.53 \\
& $645 \mathrm{c}$ & $5-20$ & $<0.01$ & $<0.01$ & 0.08 & 0.15 & 0.64 \\
& $645 \mathrm{~d}$ & $20-30$ & $<0.01$ & 0.11 & 0.21 & 0.48 & 0.74 \\
\hline
\end{tabular}

fraction although, given the minimal amount of organic matter present and its finite metal binding capacity, this is likely to include lead in the oxide form that had not been dissolved during the preceding extractions.

Most of the zinc appears in the oxide fraction, but appreciable amounts also appear in the pyrophosphate extract. Zinc oxide is less stable than lead oxide. Surprisingly, little zinc is associated with carbonate. The zinc in the pyrophosphate extract may be associated with organic matter, but, as with lead, it may represent residual oxide not previously extracted. As the battery plates were not analysed, it is not known whether the zinc is associated with lead in the battery, or was external, associated with terminal clamps, copper wiring, etc. Copper is also found in the soil associated with the lead battery, (probably derived from wiring) but only in very small amounts, mainly as the carbonate.

More can be learned about the behaviour of copper from its occurrence under a coil of copper wire (Table IV). Copper and zinc were found at high concentration in the acetic acid extract of soils from immediately below the copper wire (Table II), and were detected in material $5 \mathrm{~cm}$ down. Samples were not taken from deeper layers, and therefore the extent of movement can not be judged.

The sequential analyses (Table IV) show that under the copper wire, copper is present largely in the ionic form or as carbonate, with a smaller proportion as oxide. Only a small proportion of the copper has penetrated more than $2 \mathrm{~cm}$ into the soil. This is probably because the copper metal, has, in the first instance, to be oxidized and dissolved in what little moisture is present. It may then react with carbonate or hydroxide ions present to precipitate as copper carbonate or oxides, probably through the basic sulphates or basic carbonates $\left(\mathrm{CuSO}_{4} \cdot 3 \mathrm{Cu}(\mathrm{OH})_{3}, \mathrm{CuCO}_{3} \cdot 3 \mathrm{Cu}(\mathrm{OH})_{3}\right)$. At an adjacent site ccpper pipe was observed to be corroding, with the liberation of green copper salts on the surface of the soil. However insufficient material was available to identify these phases.

Zinc was found associated with the copper, although its origin was not obvious. It was, however, more mobile, moving further into the soil indicating greater solubility of $\mathrm{Zn}$
Table III. Results of analyses of sequential extracts from three sites associated with a crushed lead battery at Marble Point. Results expressed as $\mu \mathrm{g} \mathrm{g}^{-1}$ soil (particle size $<1 \mathrm{~mm}$ ).

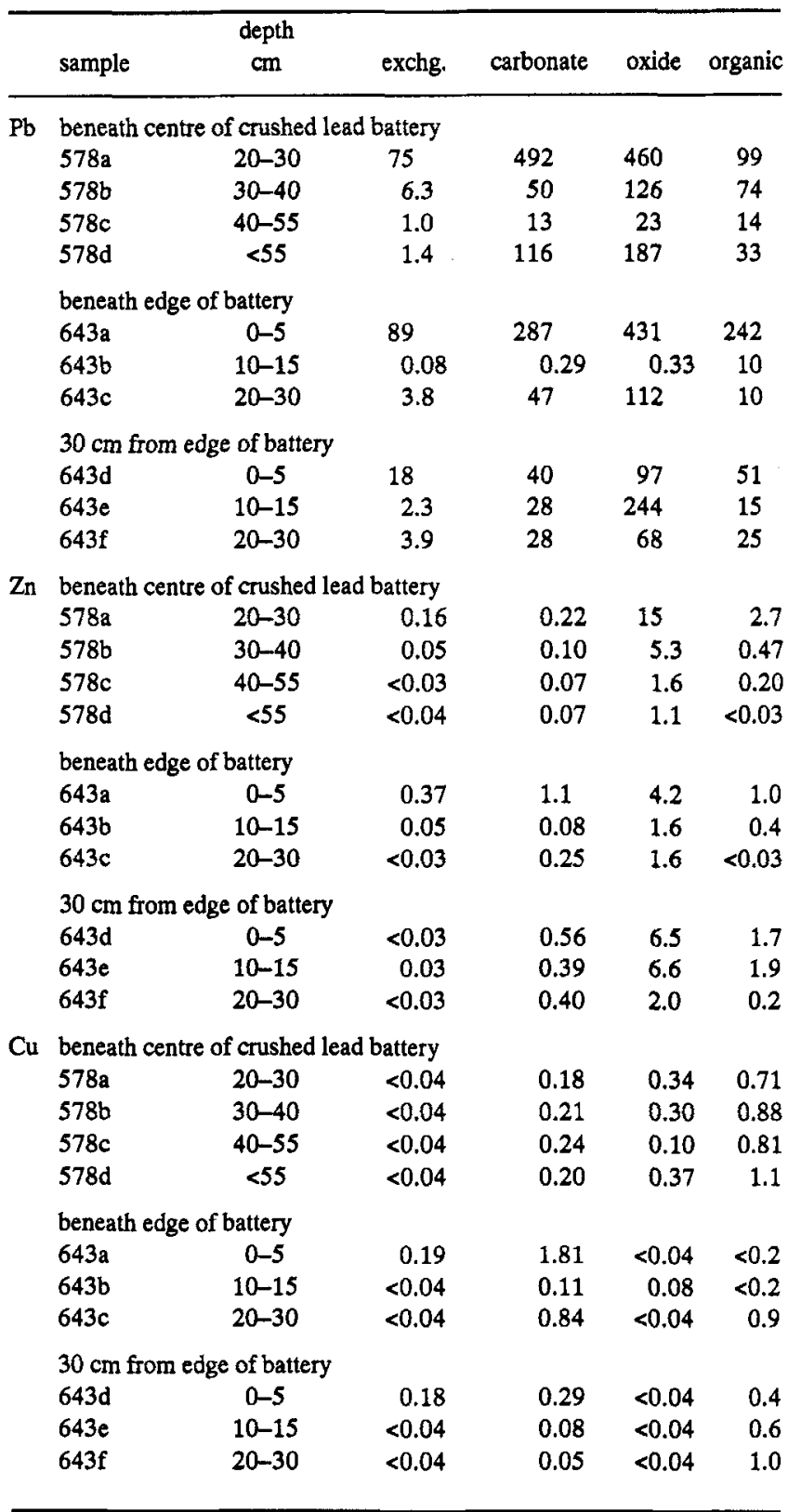

in the alkaline soil.

Under the soils contaminated by rusting cans (580), zinc levels are high, while traces of copper and lead are also present. Zinc may be present in the solder in the cans or be associated with the tinplate, although other sources of zinc, such as zinc-coated steel may also be present in the dump. At the fire site (582), levels of zinc are extremely high at the surface. It is probable that zinc-coated steel was associated with the wood (nails, bolts, wire, etc.), contributing zinc to the ash. Tin was not looked for in this study but would be expected under the rusting cans.

The sequential extractions show that at the fire site (582, 
Table IV. Results of sequential extraction of $\mathrm{Cu}$ and $\mathrm{Zn}$ from soils associated with copper wire, Marble Point $\left(\mu \mathrm{g} \mathrm{g}^{-1}\right)$.

\begin{tabular}{cccccc}
\hline & & exchangeable & carbonate & oxide & organic \\
\hline $\mathrm{Zn}$ & $579 \mathrm{a}$ & 1.5 & 1.5 & 2.7 & 1.9 \\
& $579 \mathrm{~b}$ & 5.8 & 6.4 & 11.0 & 8.4 \\
$\mathrm{Cu}$ & $579 \mathrm{a}$ & 35 & 37 & 13 & 12 \\
& $579 \mathrm{~b}$ & 1.7 & 2.1 & 1.8 & 3.8 \\
& & & & & \\
\hline
\end{tabular}

TableV)zincis present largely as the oxide, but, as a consequence of its reactivity, is also present in the ionic form, as carbonate, and in the humic fraction. The high levels of zinc in the latter fraction are more likely to result from extraction of zinc not completely released by the preceding extraction, rather than be associated with organic matter. The highest amount of lead extracted is found in the organic fraction; this may well be associated with organic matter, although pyrophosphate only extracted $0.01 \%$ organic carbon, about three times the amount found in the reference site. Copper is found largely in the carbonate and organic fractions.

The one site from Scott Base (601), (Table V) on rock of totally different composition from the reference site, also shows high levels of zinc, and appreciable amounts of lead and copper, which extend at least $20 \mathrm{~cm}$ down the profile. Zinc and lead are present largely as carbonate and oxide, with lesser amounts in the organic fraction, while copper appears largely in the organic fraction.

The origin of these heavy metals is not immediately apparent, but possible sources are leaching of zinc oxides from metal surfaces such as guy wires, garbage tins or wire mesh, lead from painted surfaces, tin cans etc., and copper from wire scraps. The buildings themselves were clad with aluminium sheet, but the passages between buildings were constructed from galvanized sheet steel (Quartermain 1971). It is evident that even without obvious contamination, human activity adds heavy metals to the environment.

\section{Discussion}

Lead

The reference site at Marble Point contains very low levels of lead, mostly as oxide. This may represent naturally occurring levels, as it is evenly distributed down the profile, but could be due to the burning of lead-containing fuels during the period of occupation of the camp. Lead levels are significantly higher in the contaminated site at Scott Base than in the reference site at Marble Point. It is possible that these levels could also arise from the burning of lead-containing fuel, but this would need to be checked by selecting a reference site on the same rock type, but remote from human activities. Some data is available from another study of soil contamination carried out around Vanda Station, some $30 \mathrm{~km}$ to the west, formed on rocks broadly similar to those at Marble Point (Sheppard et al. 1994). Using a
Table V. Results of sequential extractions of lead, zinc and copper from the site on the edge of the rubbish dump at Marble Point (580), at the fire site at Marble Point (582) and the site at Scott Base (601). Concentrations in $\mu \mathrm{g} \mathrm{g}^{-1}$.

\begin{tabular}{|c|c|c|c|c|c|c|}
\hline & sample & $\begin{array}{l}\text { depth } \\
\mathrm{cm}\end{array}$ & exchg. & carbonate & oxide & organic \\
\hline \multirow[t]{12}{*}{$\mathrm{Pb}$} & \multicolumn{6}{|c|}{ Under rusty cans, Marble Point } \\
\hline & $580 a$ & $0-2$ & $<0.1$ & 0.94 & 0.70 & 5.9 \\
\hline & $580 \mathrm{~b}$ & $0-2$ & $<0.1$ & 0.1 & 1.43 & 0.7 \\
\hline & \multicolumn{6}{|c|}{ Site of fire, Marble Point } \\
\hline & $582 \mathrm{~b}$ & $0-3$ & 4.3 & 7.9 & 32 & 126 \\
\hline & $582 c$ & $3-10$ & $<0.1$ & $<0.1$ & 0.21 & $<0.1$ \\
\hline & 583d & $10-16$ & $<0.1$ & 0.11 & 0.21 & 0.12 \\
\hline & \multicolumn{6}{|c|}{ By door, old mess hut site, Scott Base } \\
\hline & $601 a$ & $0-1$ & 0.26 & 6.6 & 33 & 37 \\
\hline & $601 b$ & $1-8$ & 0.1 & 5.3 & 9.0 & 36 \\
\hline & $601 c$ & $8-19$ & $<0.1$ & 0.56 & 0.78 & 1.2 \\
\hline & $601 d$ & $19-29$ & $<0.1$ & 0.12 & 0.17 & 0.51 \\
\hline \multirow[t]{12}{*}{$\mathrm{Zn}$} & \multicolumn{6}{|c|}{ Under rusty cans, Marble Point } \\
\hline & $580 \mathrm{a}$ & $0-2$ & 2.7 & 14 & 81 & 32 \\
\hline & $580 \mathrm{~b}$ & $0-2$ & 2.5 & 9.6 & 34 & 15 \\
\hline & \multicolumn{6}{|c|}{ Site of fire, Marble Point } \\
\hline & $582 b$ & $0-3$ & 94 & 87 & 1080 & 415 \\
\hline & $582 \mathrm{c}$ & $3-10$ & 0.16 & 1.3 & 6.7 & 1.02 \\
\hline & $583 d$ & $10-16$ & 0.22 & 1.2 & 5.5 & 1.47 \\
\hline & \multicolumn{6}{|c|}{ By door, old mess hut site, Scott Base } \\
\hline & $601 a$ & $0-1$ & 2.3 & 62 & 67 & 24 \\
\hline & $601 \mathrm{~b}$ & $1-8$ & 11.25 & 61 & 139 & 47 \\
\hline & $601 \mathrm{c}$ & 8-19 & 0.61 & 3.1 & 3.7 & 3.7 \\
\hline & 601d & $19-29$ & 0.17 & 5.1 & 22 & 7.2 \\
\hline \multirow[t]{12}{*}{$\mathrm{Cu}$} & \multicolumn{6}{|c|}{ Under rusty cans, Marble Point } \\
\hline & $580 \mathrm{a}$ & $0-2$ & $<0.04$ & 0.80 & 1.24 & 2.9 \\
\hline & $580 \mathrm{~b}$ & $0-2$ & $<0.04$ & 0.40 & 0.35 & 0.53 \\
\hline & \multicolumn{6}{|c|}{ Site of fire, Marble Point } \\
\hline & $582 \mathrm{~b}$ & $0-3$ & 1.84 & 4.7 & 1.8 & 5.1 \\
\hline & $582 \mathrm{c}$ & $3-10$ & 0.40 & 0.61 & 0.11 & 0.34 \\
\hline & $583 d$ & $10-16$ & 0.15 & $<0.04$ & 0.11 & $<0.18$ \\
\hline & \multicolumn{6}{|c|}{ By door, old mess hut site, Scott Base } \\
\hline & $601 a$ & $0-1$ & 0.14 & 0.89 & 0.41 & 2.0 \\
\hline & $601 \mathrm{~b}$ & $1-8$ & 2.2 & 6.4 & 1.7 & 5.2 \\
\hline & $601 \mathrm{c}$ & $8-19$ & 0.57 & 0.50 & 1.3 & 1.2 \\
\hline & $601 d$ & $19-29$ & 0.14 & 0.70 & 0.6 & 0.3 \\
\hline
\end{tabular}

complexing technique similar to that used for extracting oxide-held elements used here, background levels of $0.4 \mu \mathrm{g} \mathrm{g}^{-1}$ $\mathrm{Pb}$ were found.

Lead is found in significant amounts near a crushed lead/acid battery, where it is associated with carbonates and oxides. Lead/ acid batteries contain lead as a paste of lead oxide in metallic lead, and also as lead ions in solution in the sulphuric acid electrolyte. Thus lead oxide was mechanically added to the soil surface, where it could be transported laterally by wind or downward by water or mechanical mixing. It is not clear whether the site was disturbed during the crushing of the battery, or whether lead oxide particles have been moved through the soil by water from melting snow. Lead in the ionic form is found in the soil, either on the exchange complex of the very small clay 
fraction, or associated with soluble salts. It also occurs as carbonate or hydroxycarbonate, formed by precipitation of lead ions by carbonate in the alkaline soil. Lead in the ionic form is more readily mobile and has accumulated at the permafrost surface, a barrier to downward moving moisture.

\section{Zinc}

Zinc is present in higher concentrations than lead in the reference site, about $1.4 \mu \mathrm{g} \mathrm{g}^{-1}$, largely as oxide. It is possible that these levels represent some contamination. Sheppard et al. (1994) found levels of $0.3 \mu \mathrm{g} \mathrm{g}^{-1} \mathrm{Zn}$ in soils from Vanda Station.

Zincis found in relatively high concentrations associated with the lead battery. Its origin is unknown, but it may be associated with the lead in the battery itself, or with associated wiring. It is present at elevated levels in soils under copper wire, where it may originate from brass associated with the wire. Copper wire is usually extremely pure for electrical use, but brass is commonly used for fittings, terminals, etc. which may have been present. Of the three heavy metals studied zinc is present in highest amounts in the rubbish dump sites and in the site at Scott Base. It probably originates in the rubbish from protective coatings on steel, (plate, wire or nails, especially the latter); very large amounts of zinc oxide are found in the ashes of the fire site.

Zinc is relatively mobile, moving down the soil profile to accumulate at the interface between the loose soil and the ice-cemented material beneath ( sites 579 and 601). It is present in only minor amounts in the more mobile exchangeable or ionic form, and presumably this is rapidly converted to the more stable carbonate or oxide forms.

\section{Copper}

Copper is present at all of the sites studied. At the reference site it is associated with the organic fraction, which may indicate an association of copper with the traces of organic matter present in the soil. Since Sheppard et al. (1994) found comparable amounts of copper $\left(1.5 \mu \mathrm{g} \mathrm{g}^{-1}\right)$ in soils from undisturbed sites remote from Vanda Station, the values found are probably representative of uncontaminated sites.

Except where copper is obviously present, such as under copper wire, it is not an important contaminant of the soils studied. At the lead battery site, copper levels are similar to those at the reference site, while they are slightly enhanced at the rubbish dump sites and at Scott Base. It is not a very mobile constituent, and appears to remain close to its source. Presumably the major source of copper contamination of the soils is scrap copper from wire, pipe, etc.

\section{Conclusions}

This study has shown that traces of heavy metal contamination arising from human activity can be detected in Antarctic soils. Lead, zinc and copper were found close to point sources, such as crushed batteries, scattered rubbish and buildings.

The contaminants are relatively immobile. In 32 years, lead moved less than $50 \mathrm{~cm}$ laterally from a battery source and a little over $50 \mathrm{~cm}$ vertically from the source. This movement may be attributed to movement in the ionic form, and as oxide particles. Much of the lead is present as oxide. There are some indications that there may also be a more widespread contamination with lead as a result of burning of fuel.

The most widespread contaminant is zinc, which is dissolved from protective coatings on steel, or from paints. Being the most reactive of the three metal contaminants studied, it is the most mobile, and can accumulate at the base of the active layer of the soil. It is found mainly in rubbish dump sites or associated with buildings.

The levels found are not considered to represent serious pollution, but do indicate that human activities can change the chemistry of the Antarctic environment in localized areas.

\section{Acknowledgements}

The authors acknowledge the Foundation for Research, Science \& Technology, the New Zealand Lottery Grants Board for financial assistance and the New Zealand Antarctic Programme and the University of Canterbury for logistic support.

\section{References}

Amn, Z.M. 1993. Heavy metal pollution in Antarctic soils. M.Sc. Thesis, University of Canterbury, Christchurch, New Zealand. 125 pp. [unpublished]

CAMPBEL, I.B. \& CLARDGE, G.G.C. 1987. Antarctica, soils, weathering processes and environment. Amsterdam: Elsevier, 386pp.

CampBerl I.B., Claridge, G.G.C. \& Balks, M.R. 1994. The effect of human activities on moisture content of soils and underlying permafrost from the McMurdo Sound region, Antarctica. Antarctic Science, 6, 307-314.

ChAPMAN, H.D. 1965. Cation exchange capacity. In BLACK, C.A. ed. Methods of soil analysis. Madison: American Society of Agronomy, 568-577.

ELSOKKARY, I.H. \& LAG J. 1978. Distribution of different fractions of Cd, Pb, $\mathrm{Zn}$, and $\mathrm{Cu}$ in industrially polluted and non-polluted soils of Odda Region, Norway. Acta Agriculturae Scandinavica, 24, 361-368.

PowEL, H.K.J. \& Town, R.M. 1993. Ion-selective electrode potentiometric studies and the complexation of copper(II) by soil-derived humic and fulvic acids. Analytica Chimica Acta, 279, 221-233.

QuARTERMAIN, L.B. 1971. New Zealand and the Antarctic. Wellington: New Zealand Government Printer, $269 \mathrm{pp}$.

SANSOM, J. 1984. The temperature record at Scott Base, Antarctica.New Zealand Journal of Science, 27, 21-31.

Sheppard, D.S., Campaeu, I.B., Clardoge, G.G.C. \& Deely, J.M. 1994. Contamination of soils about Vanda Station, Antarctica. Institute of Geological and Nuclear Sciences Science Report 94/20. Lower Hutt: IGNS, New Zealand, 140pp.

TESSIER, A, CAMPBeu, P.G.C. \& Bisson, M. 1979. Sequential extraction procedure for the speciation of trace metals. Analytical Chemistry, 51, 844-851. 